\section{2 奏験結果}

次に各実駼結果を作図して示すことにする。

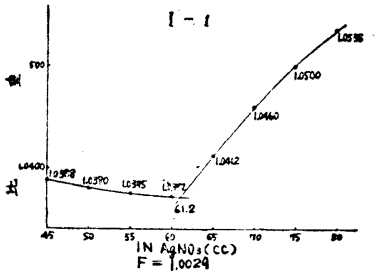

$\mathrm{Cl}^{-}(\%)$

筧法 (容量法)

60.53

本法

60.45

测定温度

$23.4^{\circ} \mathrm{C}$

[滗住]

实踰 I-1 から II-2 までは純粹な $\mathrm{NaCl}$ を試料と したもので实験 III-1 から IV-2 までは原料塩を試 料としたるのである。

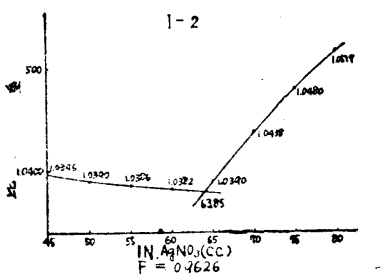

常法 (容量法)

$\mathrm{Cl}^{-}(\%)$ 本法

60.44 法

60.53

測定温度

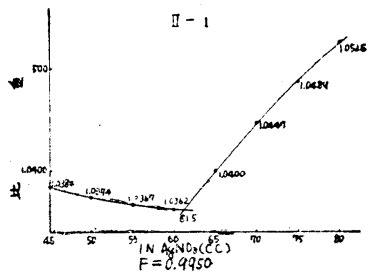

常法 (容量法)

$\mathrm{Cl}^{-}(\%)$

本法

60.67

測定温度

60.80

$24.4^{\circ} \mathrm{C}$

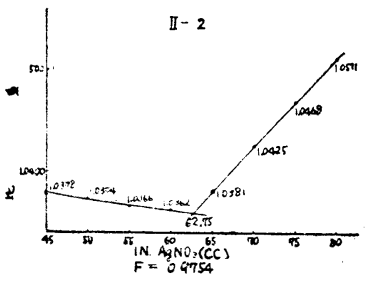

$\mathrm{Cl}^{-}(\%)$

常法 (容量法)

本法

测定温度

60.67

60.82

24. $0^{\circ} \mathrm{C}$

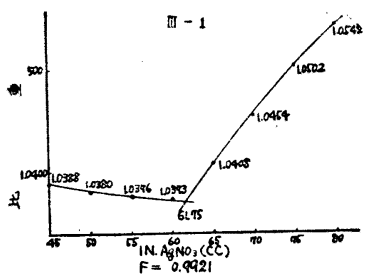

$\mathrm{Cl}^{-}(\%)$

賞法 (容等法) 57.94

本 法 57.92

測定温度 $\quad 22.3^{\circ} \mathrm{C}$

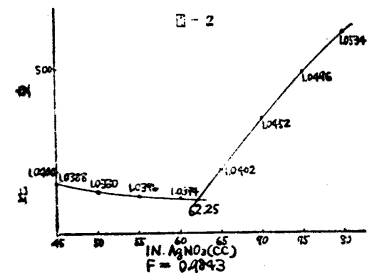

$\mathrm{Cl}^{-}(\%)$

常法 (容䕎法) 57.94

本 法 57.93

测定温度 23.0. C

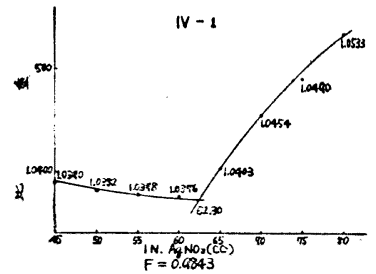

$\mathrm{Cl}^{-}(\%)$

筧法 (容量法) 57.94

本 法 57.98

测定温度 $\quad 23.0^{\circ} \mathrm{C}$

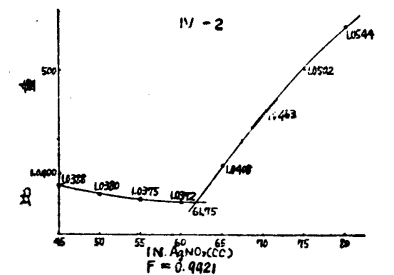

$\mathrm{Cl}^{-}(\%)$

常法 (容最法) 57.94

本 法 57.92

测定温度 $\quad 22.3^{\circ} \mathrm{C}$

\title{
総控
}

比重滴定法の研究として芒硝中の $\mathrm{SO}_{3}$ の定昷, 食塩 中の塩素の定量等を行い満足す可き結果が得られた。

本法は可成り応用範用の広いものではないかと思惟さ

れる. また白金器具および精密なビューレット等を必要

としない。本研究は著者が旭硝子株式会社牧山工場試羷 部に在勤中に行ったものである.

(立教大学理学部化学教公*)

\section{イオン交換樹脂によるアルカリ金属の分離}

（昭和28年 3 月 31 日受理）

\section{奥野 久輝・本田 雅健・石森達二郎}

イオン交換樹脂によるアルカリ金属の分離は Cohn, Kohn 両氏 ${ }^{11}$ の報告以後多くの研究があり, Kayas' ${ }^{2}$ に よる $\mathrm{Na}, \mathrm{K}, \mathrm{Rb}$ 扣よび Cs の分部隹, Rieman III等 る实際の分析への応用などがなされている。これらは水 溶液守のアルカリイオンの陽イオン交換樹脂に対する吸 着性の差異をそのまま利用したものである。また踏塩の 形成を利用したものは，ウラミル二酶酸による Buser ${ }^{4}$ の研究がある. 一方非水溶媒とくにアルコールの存在に

* 東京都豊島区池袋 ${ }^{* *}$ 東京大学理学部化学教宽
おけるアルカリイオン間の交換平衡に関しては，港機留 交撸体についての古い報告 については Kressman, Kitchener 两氏日の耶究がある にすざない，われわれはアルコールの存在に打いては, とくに $\mathrm{H}^{+}$に対する $\mathrm{Li}^{+}, \mathrm{Na}^{+}$および $\mathrm{K}^{+}$の吸着性が 增大し，またその增加の制合に望鼠があることを見出し

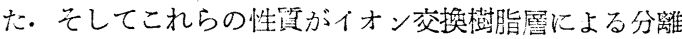
にあたって，樹脂嚿を有効に使用し，分展を確実かつ良 好にし5ることを確めた。 


\section{1) アルコールの存在における交換平衡}

アルコールの存在における $\mathrm{Li}^{+}, \mathrm{Na}^{+}$および $\mathrm{K}^{+}$の吸 着性の变化を調べるため, $\mathrm{H}^{+}$に対する（みかけの）平 衡定数 $\mathrm{K}_{\mathrm{H}}^{\mathrm{M}}$ をもとめた。 ここに, $\mathrm{K}_{\mathrm{H}}^{\mathrm{M}}=(\mathrm{MR}) \cdot\left(\mathrm{H}^{+}\right) /(\mathrm{H}$ R) $\cdot\left(\mathrm{M}^{+}\right)\left(\mathrm{H}^{+}\right)$: 液相の $\mathrm{H}^{+}$の当量数, $\left(\mathrm{M}^{+}\right)$: 液相の $\mathrm{Li}^{+}$， $\mathrm{Na}^{+}$または $\mathrm{K}^{+}$の当量数，(HR）: 樹脂相の $\mathrm{H}^{+}$ の当量数, $(\mathrm{MR})$ : 樹脂相の $\mathrm{Li}^{+}, \mathrm{Na}^{+}$または $\mathrm{K}^{+}$の当 量数.

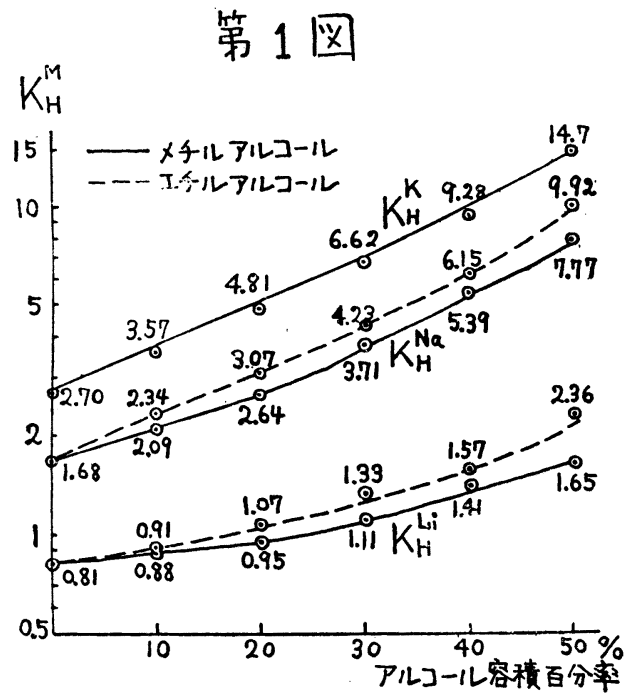

強酸型陽イオン交換樹脂 Amberlite IR-120 について メチルアルコール添加による $\mathrm{K}_{\mathrm{H}}^{\mathrm{M}}$ の变化を第1図に示す. エチルアルコールの場合も略及同一の結果をえた. 扣こ なった实験の範囲では $\mathrm{K}_{\mathrm{H}}^{\mathrm{M}}$ はともにアルコール添加に より増加し， $\mathrm{K}_{\mathrm{H}}^{\mathrm{Li}}$ は約 $20 \%$ 20 上アルコールが添加さ れれば1より大きくなる。また $\mathrm{K}_{\mathrm{H}}^{\mathrm{Li}}$ の増加の割合は $\mathrm{K}_{\mathrm{H}}^{\mathrm{Na}}, \quad \mathrm{K}_{\mathrm{H}}^{\mathrm{K}}$ の増加の割合より小さく, 樹脂層による $\mathrm{Li}$, $\mathrm{Na}$ および K の分離にあたって, アルコール類の添加は Li の分離を良好にするものと認められる.

実験 試薬：塩酸およびアルコールは蒸溜精製した。 アルカリ金属塩は,リチウム塩は市販の炭酸塩を再結晶 したものでナトリウムの焰色反応が殆んど想められない、 程度のもの, ナトリウム塩, カリウム塩はそれぞれ分析 用特級品を用いた。

Amberlite IR-120 (Rohm \& Haas 社製), HR 形の 1 0.5 $\mathrm{g}$ (風乾) にエチルアルコールまたはメチルアルコ 一ルおよびアルカリ塩化物溶液を加えて合計 $20 \mathrm{cc}$ また は 25cc とし，かつ塩化物の濃度を $0.1 \mathrm{~N}$ となるように する，密栓した三角フラスコにいれ，時及振溊して一夜 放置した後，溶液と樹脂とを分噰，樹脂は試料と同じ百 分率のアルコール水溶液で洗㴔し, 溶液と洗液を合併し て $0.2 N$ 水酸化ナトリウム溶液で滴定する. 樹脂の容量 は平衡実験に用いたものを HR 形に再生して，硫酸ナ トリウム結晶を少量加えて直接 $0.2 N$ 水酸化ナトリウム
で滴定する. 以上の 2 つの滴定值, および添加したアル カリイオンの当量より $\mathrm{K}_{\mathrm{H}}^{\mathrm{M}}$ を求めた. 平衡時に樹脂中 の $\mathrm{MR}(\mathrm{M}=\mathrm{Li}, \mathrm{Na}$ または $\mathrm{K})$ と $\mathrm{HR}$ のモル分率が略 ふ等しくなるような条件をえらんだ。

\section{2）アルカリイオン $\left(\mathrm{Li}^{+}, \mathrm{Na}^{+}\right.$むよび $\left.\mathbf{K}^{+}\right)$の分離} 定量

Amberlite IR-120(100 メッシュ以下の粒度) の $12 \mathrm{cc}$ (水中みかけの容積), 高さ $8 \mathrm{~cm}$ の $\mathrm{HR}$ 形樹脂層を用 いて, およそ計 $5 \mathrm{~m}$. eq. 以下のアルカリイオン混合溶液 について,メチルアルコール・塩酸を溶離液として室温 で分㒕実験を試み，アルコールの添加が有効であること を確めた。
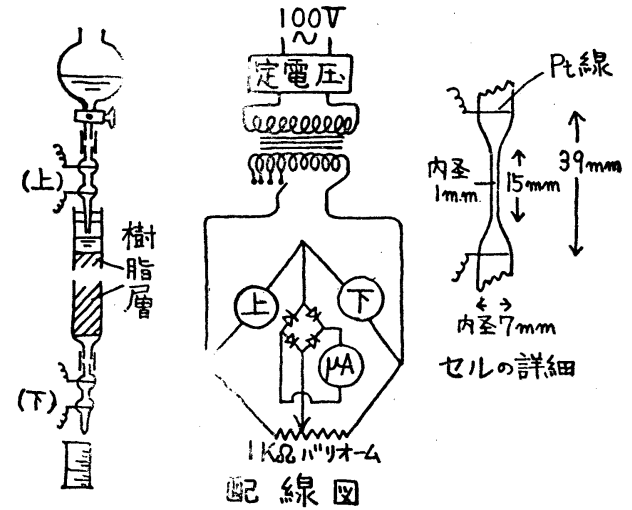

第2図 HCl の場合は特に流速によって影響を5 けやすい.Wickbold のセルに近いが，基準セル を流大液の方に拈いて，示差的な值をよみとれる ようにすると同時に，流速の影辠をかなり防止し えた。
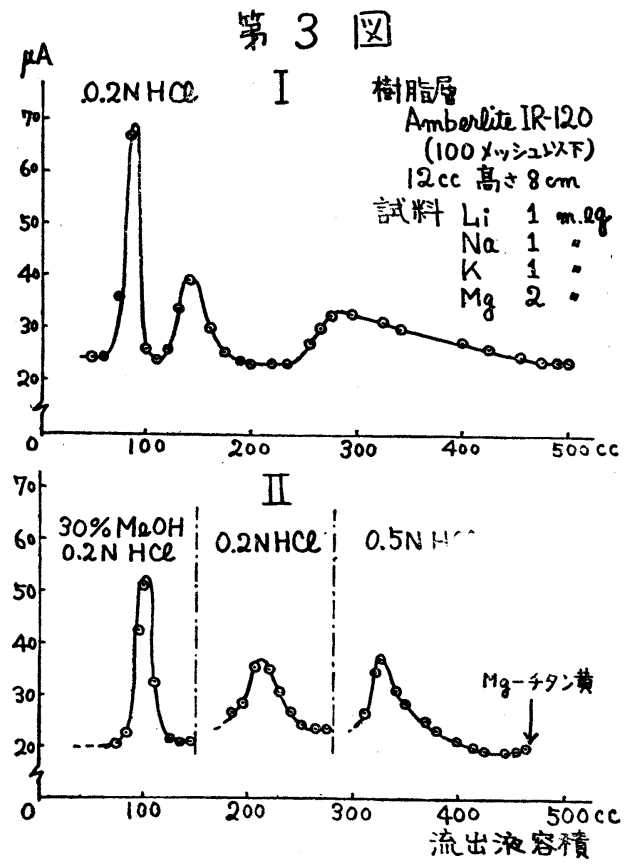
溶離液の検討 : アルカリイオンの溶離の状洗は Glueckauf $^{7}$, Wickbold ${ }^{8}$, 南・垣花・藤本 ${ }^{9}$ 等のごとく電導 度の变化を求めて测定した。装置は第 2 図のようなもの とした. $\mathrm{Li}^{+}, \mathrm{Na}^{+}$および $\mathrm{K}^{+}$(塩化物) それぞれ $\mathrm{lm}$. eq., $\mathrm{Mg}^{++}$(塩化物 $) 2 \mathrm{~m}$. eq の混合溶液について溶離液の 検討をした結果の一部を第 3 図に示す. $\mathrm{Mg}^{++}$はチタン 葓によって稣出した. これらの例では混合溶液中のイオ ンを樹脂層上部に吸着させて水洗した後, 種々の溶離液 で流速およそ $100 \mathrm{cc} / \mathrm{hr}$. で分別溶離をおこなった場合で ある、第 3 図 I見られるよ $5 に ， 0.2 N$ 塩酸のみによ る溶漓では $\mathrm{Li}^{+}$と $\mathrm{Na}^{+}$の分離が充分でなく，また $\mathrm{K}^{+}$

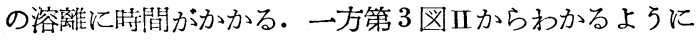
溶離液にメチルアルコールを添加し，また塩酸の濃度を 变えることによって溶離の状沅は良好となる。

分離定量の実験; $\mathrm{Li}^{+}, \mathrm{Na}^{+}$および $\mathrm{K}^{+}$混合試料につ いて塩化物濃度扎よそ0.1N，メチルアルコール 20〜30 \%とした溶液を，20〜30\%メチルアルコール水溶液で前 処理をした樹脂層に流入し，水溶液で洗浄して試料中の 全アルカリイオンを樹脂層上部に吸着させる・その後流 出液の電導度の变化を観察しながら， $\mathrm{Li}^{+}$の溶離を $30 \%$ メチルアルコール・ $0.2 N$ 塩酸溶液でおこない，つぎに $\mathrm{Na}^{+}$と $\mathrm{K}^{+}$の溶離をそれぞれ $0.2 N$ 塩酸と $0.5 N$ 塩酸 にておこない, 各流出部分の溶液は激浴上で蒸発乾涸し て水に溶解，0.1N 硝酸銀溶液によって Mohr 滴定をお こなって定量した.この際に滴定前に滴定液にメチルオ レンジを加え, 液が酸性を示すときは $0.2 N$ 水酸化ナト リウム溶液で中和後に mohr 滴定をおこない, 硝酸銀溶 液滴定值に補正をなしてアルカリイオンの定量をした。

算 1 表

アルカリイオンの分離定星

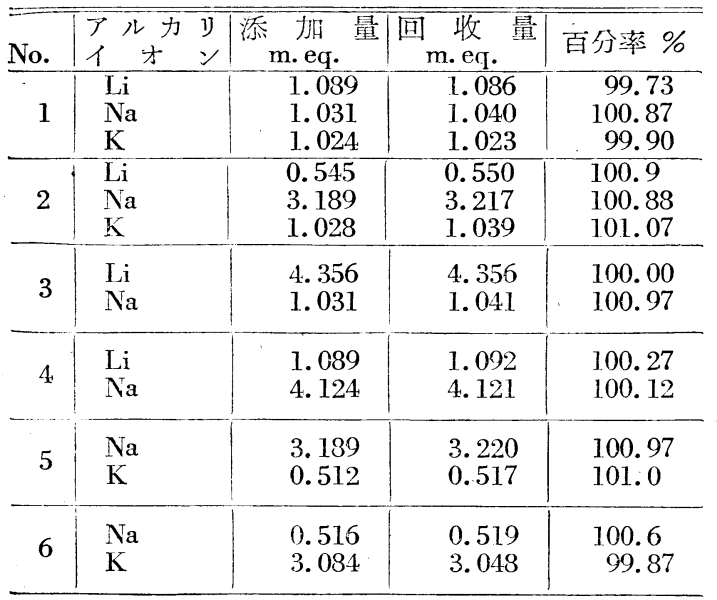

分離定量の結果を第 1 表に示す. 実験 No. 5 と No.6 は $\mathrm{Ii}^{+}$を会まない場合であるが， $\mathrm{Na}^{+}$の溶離を $0.2 \mathrm{~N}$ 塩酸のみでふこなうときは $\mathrm{K}^{+}$との分離が不完全であっ たので, $\mathrm{Na}^{+}$の溶離には $10 \%$ チルアルコール・0.2N
塩酸浴液を用いた結果である. 各組成の混合試料に対す る実験のうち代表的なものについて, その溶離曲線を第 4 図に示す.

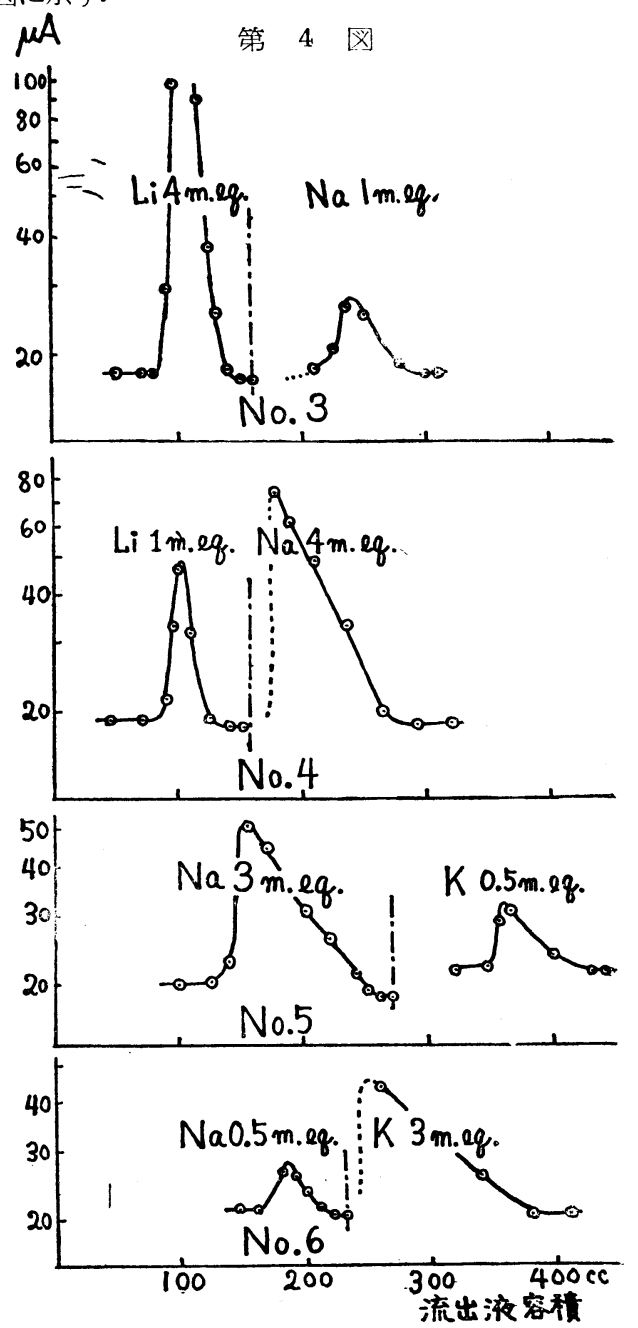

分離定量の結果扣よび溶漓倠曲線より，分離が充分おこ なわれていることがわかる，定量的な回收の精度は時に 土 1 \%程度になることがあったが，各流出部分にえられ たアルカリイオンの純芰はさらに高いものと思われる.

\section{3) 塩化リチウムの崝製 (Na の除去)}

アルカリイオンの分離と同椂に陽イオン交換樹脂噟に よってリチウム盐の精製方洼を検討した。

最も䦐題となる共存する金属イオンとして，少量の+ トリウムイオンを侾る.たとえば $\mathrm{K}_{\mathrm{Li}}^{\mathrm{Na}}=3$ なる場合の 精製過程は算 5 图のよ5に能えられるから，良好な条件 のもとでは，少量のナトリウムイオンを含むときは原液 のナトリウムイオンの含臽にかかわらず，使用した樹脂 塬の交換容量の約 $(3-1=) 2$ 倍までのリチウム塩浴液 を精製することができる箱である．勿論アルコール含量 を増大すればさらに能率がよくなる䉪であるが，大量を 颃う際のアルコールの節約を考劣，また原理的に同一で 
あるからこの場合について検尉した。

実験：小規模のものでおこなった.

第 5 叉樹脂層は AmberliteIR-120

(粒湾市販のまま)，水中みか

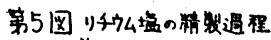
$K_{L i}^{\mathrm{Na}}=3$ の場合 $=2 \cdots x$

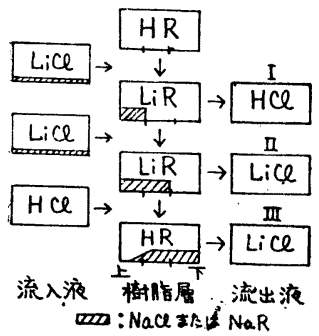
けの容積 $100 \mathrm{cc}$, 高さ $15 \mathrm{~cm}$, 交換容量 $200 \mathrm{~m}$. eq. のむのを 使用した，原液には不純の市 販塩化リチウムを溶解，メチ ルアルコールを加えて塩素イ オン濃度 $0.4 \sim 0.6 N$, アルコ ール 25\%ににしたるのを用い たここでメチルアルコール25 \%溶液に扎いては $\mathrm{K}_{\mathrm{H}}^{\mathrm{Li}} \fallingdotseq 1$, $\mathrm{K}_{\mathrm{H}}^{\mathrm{Na}} / \mathrm{K}_{\mathrm{H}}^{\mathrm{Li}} \fallingdotseq 3$ である.

第 2 表 塩化リチウムの精製

\begin{tabular}{|c|c|c|c|c|}
\hline 液 & 流出液 1 & 流 出 液 2 & 流出液 3 & 收量 \\
\hline No. $\left.1_{\mathrm{CH}_{3} \mathrm{OH} 25 \%}^{\mathrm{LiCl} 0.6_{0} \mathrm{~N}^{*}}\right\} 750 \mathrm{cc}$ & & $250-750 \mathrm{cc}$ & $750-1050 \mathrm{cc}$ & $15 \mathrm{~g}$ \\
\hline 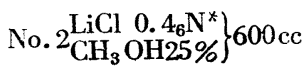 & $\dot{0}-200 \mathrm{cc}$ & $200-600 \mathrm{cc}$ & $600-1000 \mathrm{cc}$ & $7.6 \mathrm{~g}$ \\
\hline
\end{tabular}

樹脂層: Amberlite IR-120 約 $200 \mathrm{~m}$. eq. 高さ $15 \mathrm{~cm}$, 径 $3 \mathrm{~cm}$ 流 出液 3 : No. 1 と No. 2 はそれぞれ $0.5 \mathrm{NHCl}-25 \% \mathrm{CH}_{3} \mathrm{OH}$ $0.4 N H C l$ による流出液。

* 塩化物規定度

第 2 表に実例の一部を示す. HR 形に再生, 水洗した 上記の樹脂層に原液を流大し，流速 $100 \sim 150 \mathrm{cc} / \mathrm{hr}$ で通 過させる. 第 2 表において, 流出液 1 と流出液 2 はとも に原液を流大した際の流出液の一部であり, 前者は塩酸 が主成分であるので, 廃䢂する流出液· 3 は塩酸を流大し た際の流出液であり, 流出液 2 と合併して石英ビーカー 内で蒸発乾涸した後, 小量の水に溶解，白金血で蒸発乾 涸，強熱して有機物を分解する。

流出液 1 と流出液 2 との境界は，焰色反応によって充 分リチゥムの焰色が喼められるに至った点とし，その後 の流出液を流出液 2 とする，リチウムの溶離は樹脂層の 交換容量から考えられるよりも幾分早くおこなわれた。

精製の度合 : 精製した塩化りチウム中のナトリウムは 焰光分光分析法で哈味した.

Perkin Elmer 社製の Flame Photometer, 塩化リチウ 么標準溶液を用いておこなった。焰光スペクトルのナト リウムの D線, またはとの附近のブランクの強度は大量 のリチウムの共存によって著しく影響される（弱められ る）ので，塩化リチウム標淮溶液に塩化ナトリウム溶液 を加えて標準液列を調製して検舀線をつくって分析をお こなった。

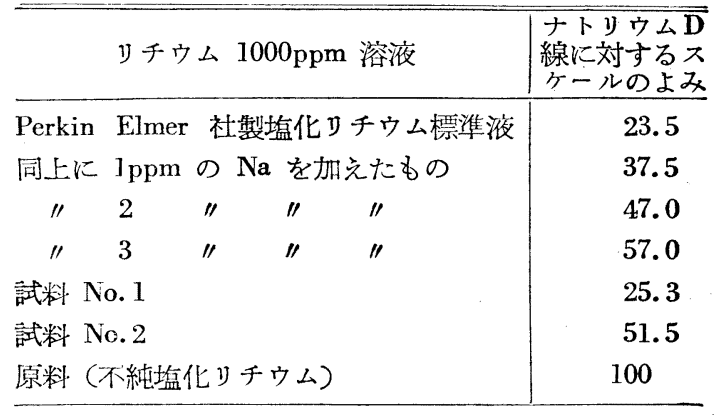

故に No. 1 の試料は $0.1 \% \mathrm{Na}$ またはとれ以下と認め

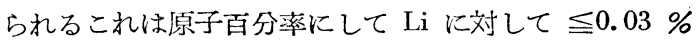
$\mathrm{Na}$ といえる. 焰光分析の標準用に精製する目的ならば 溶液のままでよいから，操作は非常に省けるし濃縮その 他の操作の途中にナトリゥムで泿染される心配がない。

\section{総 括}

アルコールの存在によるイオン交換平 衡の移動は, イオン交換樹脂層を用いる アルカทイオンの分離に有効に適用され る，分離実験に打いては，少くとも $5 \mathrm{~m}$. eq. のアルカリイオン混合物を12cc（交 换容量 $25 \mathrm{~m}$. €q.) のイオン交換樹脂で 分離することができた・これは一定量の 樹脂量で従来の報告にみられない多量の 物質の分離を可能とすることを示している．また分離操 作を確実かつ容易にするものである.この方法は $\mathrm{Rb}$, Cs を含めてアルカリ金属のみならず，一般に他の物質 の分離にもよく利用されるものと考えられる。また $\mathrm{K}_{\mathrm{H}}^{\mathrm{Li}}$ が1よりも大きくなることを見出したが，このことはイ オン交換樹脂によるリチウム壏の処理にあたって利用価 值が大きいと思う なお本法を Amberlite IR-112 につ いても試みたが，IR-120 に比して劣る結果をえた。

純リチウム塩の精製法としてイオン交換樹脂が有効に 用いられることがわかった. この方法は, 従来の熱水よ りの炭酸リチウムの再結晶法に比して, 比較的大規模な 精製に一噟適していると思われる。

Flame Photometer による測定については, 東京工業 試験所，石田良平氏に御援助を戴いた。ここに深謝す る. (1952年10月分析化学会第 1 年会にて講演)

\section{文献}

1) W. E. Cohn, H. Kohn : J. Am. Chem. Soc., 70, 1986 (1948)

2) G. Kayas: J.chim.phys., 47,408 (1950)

3) R. C. Sweet, W. Rieman III, J. Beukenkamp : Anal. Chem., 24, 952 (1952)

4) W. Buser : Helv. Chim. Acta., 34, 1635(1951)

5) G. Wiegner, H. Jenny : Kolloid. Z., 42, 270 (1927)

6) T. R. E. Kressman, T. A. Kitchener : J. Chem. Soc., 1949, 1211. 
7) E. Glueckauf : J. Chem. Soc., 1947, 1036

8) R. Wickbold : Z. anal. Chem., 132, 406
(1951)

9）南英一, 垣花秀武, 藤本昌利 : 日化, 73,368(1952)

(旭硝子株式会社牧山工場試験部*)

\title{
硫酸根の定量に対する新容量分析法
}

\author{
（昭和28年 4 月 10 日受理）
}

新海重行**

\section{I 䌐 䨐}

硫酸根の容量分析法としては，内部指示薬としてロヂ ゾン酸ソーダを用いる Mutschin und Pollak ${ }^{1}$ の方法拈 よび塩酸ベンヂヂンを用いる Kurtenacker ${ }^{21}$ の方法があ る.

蓞者の検討実験によると前者は $5 \mathrm{gNa}_{2} \mathrm{SO}_{4} / 1\left(\mathrm{SO}_{3}\right.$ と して約 $0.07 N$ ) の濃度では指示薬の色变に相当时間がか かり終点の判定が困難であった. $\mathrm{SO}_{3}$ の濃度が小になる ほど終点は益々不明瞭になる・後者は常に高い值を与え て余り正確な方法とは思われない，故に著者の研究した 方法について報告したいと思う。

\section{II 定量機構}

例を艺硝にとってその定量機構を述べてみよう。

艺硝の水溶液に過剩の $\mathrm{BaCl}_{2}$ 水溶液を作用させた後, その過剩の $\mathrm{BaCl}_{2}$ に $\mathrm{Na}_{2} \mathrm{CO}_{3}$ 溶液の過剩を加兄, その 過剩の $\mathrm{Na}_{2} \mathrm{CO}_{3}$ を酸の規定液で滴定して $\mathrm{BaCl}_{2}$ によっ て消費された $\mathrm{Na}_{2} \mathrm{CO}_{3}$ を求めると, $\mathrm{Na}_{2} \mathrm{SO}_{4}$ によって消 費された $\mathrm{BaCl}_{2}$ が判るから, それによって $\mathrm{SO}_{3}$ を算出 することが出来る. その反忘は次式によって示される.

$$
\begin{aligned}
& \mathrm{Na}_{2} \mathrm{SO}_{4}+\mathrm{BaCl}_{2}=\mathrm{BaSO}_{4}+2 \mathrm{NaCl} \\
& \mathrm{BaCl}_{2}+\mathrm{Na}_{2} \mathrm{CO}_{3}=\mathrm{BaCO}_{3}+2 \mathrm{NaCl}
\end{aligned}
$$

\section{III 定量方法}

艺硝の $50 \mathrm{~g}$ を水の $1 l$ に溶解したものを試料として 使用した. 試料液の $20 \mathrm{cc}$ を $400 \mathrm{cc}$ のビーカーに採り, 若し遊離酸が存在するときは指示薬としてメチルレッド を用いて $\mathrm{N} / 10 \mathrm{NaOH}$ で中和した後, 水で 100cc に稀釈 乙て者沸し別に $\mathrm{N} / 2 \mathrm{BaCl}_{2}$ 溶液の $30 \mathrm{cc}$ を煮沸してこれ を熼捧しながら徐及に加える・それを冷却した後 $250 \mathrm{cc}$ のメスフラスコに移し水で標線まで稀釈してよく振盪し 約 3 分間遠心分離して上澄液の $200 \mathrm{cc}$ を採って $250 \mathrm{cc}$ のメスフラスコに移し， $\mathrm{N} / 2 \mathrm{Na}_{2} \mathrm{CO}_{3}$ の $10 \mathrm{cc}$ を加え水で 標線まで稀釈してよく振軴する.これを約 3 分間遠心分 陮して上澄液の $200 \mathrm{cc}$ を $400 \mathrm{cc}$ のビーカーに採り，予 倫実験として子め $1 N H C l$ でメチルオレンヂを指示薬と して中和滴定を行いその滴定数 (cc) よりも lcc を過剩 に扣え，10分間煮沸して $\mathrm{CO}_{2}$ を完全に追い出し冷却し

\footnotetext{
* 八幡市

** 戸畑市沢見通 3 の 3
}

た後メチルレッドを指示薬として， N/10NaOH溶液逆滴 定し次式によって $\mathrm{SO}_{3}$ を算出する.

$2.0015^{*} \times\left[\mathrm{N} / 2 \mathrm{BaClcc}-\left[\mathrm{N} / 2 \mathrm{Na}_{2} \mathrm{CO}_{3} \mathrm{cc}-\{(1 N \mathrm{HClcc} \times\right.\right.$ $10-\mathrm{N} / 10 \mathrm{NaOHcc}) \times 1 / 5 \times 5 / 4\}] \times 5 / 4]=\mathrm{SO}_{3}(\%)$

$* \mathrm{~N} / 2 \mathrm{BaCl}_{2} \mathrm{lcc}=0.020015 \mathrm{gSO}_{3}$

IV 実験結果

実験結果を次に表示する。

\begin{tabular}{|c|c|c|c|c|c|c|c|}
\hline $\begin{array}{l}\text { 実驗 } \\
\text { 番号 }\end{array}$ & 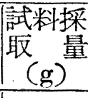 & $\mid \begin{array}{l}\mathrm{N} / 2 \mathrm{Ba} \\
\mathrm{Cl}_{2} \text { 添 } \\
\text { 加量cc }\end{array}$ & $\begin{array}{c}\mathrm{N} / 2 \\
\mathrm{Na}_{2} \mathrm{CO}_{3} \\
\text { (cc) }\end{array}$ & $\begin{array}{r}1 N \\
\mathrm{HCl} \\
(\mathrm{cc})\end{array}$ & \begin{tabular}{|c}
$\mathrm{N} / 10$ \\
$\mathrm{NaOH}$ \\
$(\mathrm{cc})$
\end{tabular} & $\begin{array}{l}\mathrm{N} / 2 \mathrm{Ba} \\
\mathrm{Cl}_{2} \\
\text { 費量 } \\
\end{array}$ & $\begin{array}{l}\mathrm{SO}_{3} \\
(\%)\end{array}$ \\
\hline 1 & 1.0000 & 30.07 & 9.99 & 4.657 & 12.88 & 23.12 & 56.28 \\
\hline 2 & II & 11 & $\prime \prime$ & 11 & $12 \cdot 75$ & 28.14 & 56.32 \\
\hline 3 & " & 30.17 & 10.45 & 4. 698 & 11.60 & 28.17 & 56.38 \\
\hline 4 & "I & "I & $" 1$ & "I & 11.54 & 28.18 & 56.40 \\
\hline 5 & "I & "I & "I & "I & 11.62 & 28.16 & 56.36 \\
\hline 6 & "I & "I & "I & "I & 11.63 & 28.16 & 56.36 \\
\hline 7 & "I & "I & " & " & 11.57 & 28.17 & 56.38 \\
\hline 8 & "I & "I & "I & " & 11.60 & 28.17 & 56.38 \\
\hline 9 & "I & "I & " & " & 11.55 & 28.18 & 56.40 \\
\hline 10 & " & "I & " & "I & 11.56 & 68.18 & 56.40 \\
\hline 11 & "I & "I & "I & "l. & 11.71 & 28.13 & 56.30 \\
\hline 12 & "I & "I & " & " & & 28.13 & 56.30 \\
\hline 13 & " & "I & "I & " & 11.64 & 28.15 & 56.34 \\
\hline 14 & " & " & " & " & 11.67 & 28.14 & 56.32 \\
\hline 15 & " & "I & " & "I & 11.65 & 28.14 & 56.32 \\
\hline 16 & " & "I & " & 4.707 & & 28.17 & 56.38 \\
\hline 17 & " & "I & "I & "I & 11.65 & 28.18 & 56. \\
\hline 18 & " & "I & " & "I & 11.75 & 28.14 & 56.32 \\
\hline 19 & " & " & " & "I & & 28.13 & 56.30 \\
\hline 20 & I" & "I & " & "I & 11.68 & 28.17 & 56.38 \\
\hline \multirow{2}{*}{\multicolumn{2}{|c|}{$\begin{array}{l}\text { 平均值 } \\
\text { 重量分析值 }\end{array}$}} & & & & & & \\
\hline & & & & & & & 56.35 \\
\hline
\end{tabular}

第 1 表

次に Mutschin および Pollak の方法を仮りにロヂジ ン酸ソーダ法と呼び Kurtenacker の方法を塩酸ベンヂ ヂン法と呼ぶことにする. その検討実験結果を次に表示 する・

A ロヂゾン酸ソーダ法

数 cc の $0.2 \mathrm{NBaCl}_{2}$ 溶液を $500 \mathrm{cc}$ のビーカーに採 り,これに $2 \mathrm{~g}$ の $\mathrm{NH}_{4} \mathrm{Cl}$ と $35 \mathrm{cc}$ の $\mathrm{CH}_{3} \mathrm{COCH}_{3}$ と を加え水で $100 \mathrm{cc}$ に稀釈して, ロヂゾン酸ソーダ 溶液 $(10 \mathrm{mg} / 5 \mathrm{cc})$ の $1 \mathrm{cc}$ をピペットを用いて添加し 1-2 分間放置して青赤色を発色した後ビューレット から試料液で滴定し, 褐赤色となったら充分䚌拌し ながら 1 滴で登色から澄明な黄色に变化するまで滴 定する. 